Zainab A. AL-Dahan BDS, MSc, (Prof)

Ghaeth H. Al-Jobory BDS, MSc (Assist Lect)

\section{Dental erosion among 11-12 years old children in Mosul city}

\author{
Dept of Pedodontics, and Preventive Dentistry
}

College of Dentistry, University of Baghdad

Dept of Pedod, orthod, and Prev Dentistry

College of Dentistry, University of Mosul

\begin{abstract}
Aim: to determine the prevalence of erosion in children and to compare different etiological factors related to dental erosion. Materials and Methods: A study of dental erosion conducted among 3125 children, 11-12 years old which represent delay mixed dentition in 27 primary schools in Mosul city, comprising a study group with 35 erosion children, 22) males and 13 females. The other compared controlled subject are 35 children without erosion and caries free random sampling matching for both age and sex. The level of erosion was recorded using modified tooth wear index (MTWI), standardized methods for salivary flow rate and PH measurements were conducted. The role of various possible factors related to oral health in general and to dental erosion in particular was assessed for both study and control groups by means of multiple choice questionnaire. Results: showed that the prevalence of erosion in the sample was $14.3 \%$ distributed as mild erosion (7.55\%), moderate erosion (5.6\%) and only sever erosion $(1.15 \%)$. A significant lower salivary flow rate mean $(0.38 \pm 0.38 \mathrm{ml} / \mathrm{min})$ and salivary PH mean $(7.35 \pm 0.37)$ in erosion group were found, whereas in the control group they were $0.47 \pm 0.19 \mathrm{ml} / \mathrm{min}$ and $7.50 \pm 0.25$ respectively. The results demonstrated a significant higher fruit juice intake, carbonated drink intake in erosion group than in their controls. The erosion group showed no significant difference in drinking habit and time of drinking of the soft drink compared with control group. Conclusion: The dental practitioners must be aware of their important role to recognize dental erosion and understanding its pathogenesis so that correct diagnosis and management of erosion can be performed.
\end{abstract}

Key words: Erosion, Soft drink, Prevalence, Saliva

AL-Dahan ZA, Al-Jobory GH. Dental erosion among 11-12 years old children in Mosul city. AlRafidain Dent J. 2006; 6 (Sp Iss): 58S-63S.

Received: $4 / 5 / 2005$

Accepted for Publication: 12/6/2005

\section{INTRODUCTION}

Dental erosion is a loss of tooth substance by a chemical process that does not involve known bacterial action. ${ }^{(1)}$

Dental erosion is a part of the comm.on term tooth wear used to describe the surface loss of the dental hard tissue, which may also result from attrition or abrasion. ${ }^{(2)}$ Over the past few years there had been steady increase in reports of erosion seen especially in young adults, adolescents and young children. ${ }^{(3)}$

Although the causes of erosion are multifactorial, there is increasing evidence that acidic dietary components such as soft drinks are directly related to dental erosion. ${ }^{(4)}$ Erosion is not linked simply to high intake of acidic beverages but also to the frequency, method and the timing of cons- umption $^{(5)}$, therefore the potential risk factors of dental erosion are the change in lifestyles and eating patterns which encourage the increase consumption of acidic food and drinks. ${ }^{(6)}$ Salivary factors such as buffering capacity, $\mathrm{PH}$ and flow rate also may play an important role in the etiology of erosion. ${ }^{(7)}$ Jarvinen et al. ${ }^{(8)}$ showed that unstimulated salivary flow rate of $0.1 \mathrm{ml} / \mathrm{min}$ or less produce a five times greater risk of erosion than the higher flow rate.

Since the last occupational war in Iraq, the increase of soft drinks consumption should be considered one of the most important new lifestyle changes, especially in young children and adolescents and this may increase the risk of dental erosion especially in these groups. No previous Iraqi 
study concerning erosion among children and adolescents has been conducted; therefore this study was carried out to open the door widely for the understanding of dental erosion in Iraq.

The aims of the study were to establish the prevalence of erosion in children in Mosul city, measure and compare the $\mathrm{PH}$ and flow rate of saliva in children with erosion and their controls, determine the relationship between dental erosion and acidic soft drink intake in children, determine the effect of drinking habit and time of drinking on the occurrence of dental erosion.

\section{MATERIALS AND METHODS}

After identifying the schools and geting approval of the Ministry of education to carry out this study, a contact with school authorities was made to explain the purpose of the study, 3125 children aged 11-12 years were participated in the study, the sample was selected from two areas of
Mosul city, 1437 children from twelve primary schools were chosen from the right side area of Mosul city and 1688 children from fifteen primary schools were chosen from left side area of Mosul city.

All of children found with sever erosion were considered as study group in order to establish possible associated risk factors. ${ }^{(9)}$ Equal number of children to the study group match for age and gender were chosen from same schools, they were had no evidence of dental erosion and no clinical carious lesion ${ }^{(10)}$, so both study and control groups represent individuals with contrasting level of dental erosion. ${ }^{(9)}$

Examination was performed in the class room under natural light with the aid of dental mirror and explorer. Teeth were dried using cotton wools; the surfaces of all teeth present in the mouth were scored for dental erosion according to tooth wear index by Smith and Knight ${ }^{(11)}$ modified by Millword et al., ${ }^{(12)}$ (Table 1).

Table(1): Diagnostic Criteria fo12Modified Tooth Wear Index (MTWI)

\begin{tabular}{|c|c|c|}
\hline Score & Criteria & Surfaces \\
\hline $\mathbf{0}$ & No loss of enamel surface characteristic & $\mathrm{B}, \mathrm{L}, \mathrm{O}, \mathrm{I}$ \\
\hline 1 & Loss of enamel surface characteristic & $\mathrm{B}, \mathrm{L}, \mathrm{O}, \mathrm{I}$ \\
\hline \multirow[t]{2}{*}{2} & $\begin{array}{l}\text { Loss of enamel, visible dentin on less than a third of the surface } \\
\text { area }\end{array}$ & $\mathrm{B}, \mathrm{L}, \mathrm{O}$ \\
\hline & Loss of enamel with visible dentin & I \\
\hline \multirow[t]{2}{*}{3} & $\begin{array}{l}\text { Loss of enamel, visible dentin on more than a third of the } \\
\text { surface area }\end{array}$ & $\mathrm{B}, \mathrm{L}, \mathrm{O}$ \\
\hline & $\begin{array}{l}\text { Loss of enamel, and substantial loss of dentin but not exposing } \\
\text { pulp or secondary dentin }\end{array}$ & I \\
\hline \multirow[t]{2}{*}{4} & $\begin{array}{l}\text { Complete loss of enamel, pulp exposure, or exposure of } \\
\text { secondary dentin }\end{array}$ & $\mathrm{B}, \mathrm{L}, \mathrm{O}$ \\
\hline & Pulp exposure or exposure of secondary dentin & I \\
\hline 9 & $\begin{array}{l}\text { Excluded from analysis (missing tooth, partially erupted, large } \\
\text { restoration, extensive caries, orthodontic band, composite } \\
\text { restoration, any crowns, tooth fracture, and fissure sealant) }\end{array}$ & $\mathrm{B}, \mathrm{L}, \mathrm{O}, \mathrm{I}$ \\
\hline
\end{tabular}

B: Buccal or Labial; L: Lingual or Palatal; O: Occlusal; I: Incisal; In cases of doubt the lower score was assigned

The children with erosion were also classified into one of three groups:

* Mild erosion: Any surface with score of 1

* Moderate erosion: Any surface with score of 2
* Sever erosion: Any surface with score of 3 and/or 4

Certain questions regarding acidic soft drink intake were checked by interviewing each child because it is 
easier and more reliable to be answered by the child.

The method of saliva collection was done according to Lussi, ${ }^{(13)}$ the collection was done in the mid morning about 10 a.m., and each child was instructed not to eat or drink any thing 2 hours preceding the appointment. For the collection of unstimulated saliva the child was seated comfortable, with his head bent forward and after an initial swallow spit out into tube via sterilized funnel, the time for collection period was 5 minutes and then converted to milliliters per minute in order to measure the salivary flow rate. ${ }^{(10)}$ The salivary $\mathrm{PH}$ of saliva was measured directly using a $\mathrm{PH}$ meter calibrated using buffers of $\mathrm{PH} 4$ and 7. The accuracy of PH meter was checked at each time of use to insure that the readings were correct.

The data were analyzed using SPSS package; means and standard deviation were calculated. Statistical analysis of data was done using Student's t-test and Chisquare test and $P$ value at 0.05 level.

\section{RESULTS AND DISCUSSION}

The prevalence of dental erosion in the sample was $14.3 \%$ as shown in Table (2) which distributed as mild erosion $(7.55 \%)$, moderate erosion $(5.6 \%)$, and sever erosion $(1.15 \%)$. The prevalence of exposed dentin due to erosion in the sample was $6.75 \%$, which is lower than that reported by Millword et al., ${ }^{(12)}$ which was $48 \%$. No exposed dentin due to erosion was noticed in permanent teeth, this was in accordance with Deery et al., ${ }^{(14)}$, while it is lower than that reported by AL-Majed et $a l .,{ }^{(15)}$ and Dugmore and Rock ${ }^{(16)}$ that showed $26 \%$ and $2.7 \%$ of exposed dentin in permanent upper centrals respectively.

The reasons for the wide range prevalence of erosion in both primary and permanent dentition in different studies may be related to the relatively small number of subjects in the majority of the studies, the use of different criteria for diagnosis and the society that persons live in.

Table (3) represented that the mean salivary flow rate and $\mathrm{PH}$ in both study and control group, the study group had significantly lower mean salivary flow rate and $\mathrm{pH}$ than the control group $(\mathrm{P}<0.05)$. This finding was consistent with the results of O'Sullivan and Curzon ${ }^{(17)}$ and Sanchez and Preliasco ${ }^{(10)}$; however Bartlett et $a l .,{ }^{(18)}$ and Johansson et al. ${ }^{(9)}$ reported that no significant difference. The marked individual variations, the lack of circadian rhythm and the small size of the samples may be responsible for this disagreement.

Table (2): Prevalence of erosion in tested sample

\begin{tabular}{ccccc}
\hline \multirow{2}{*}{ Severity } & \multicolumn{2}{c}{ Number } & \multirow{2}{*}{ Total } & \multirow{2}{*}{ Percentage } \\
\cline { 2 - 3 } & Male & Female & & \\
\hline Mild & 120 & 116 & 236 & 7.55 \\
Moderate & 103 & 72 & 175 & 5.6 \\
Severe & 23 & 13 & 36 & 1.14 \\
Total & 246 & 201 & 14.30 & 14.3 \\
\hline
\end{tabular}

Table (3): Salivary flow rate and salivary PH of study and control group

\begin{tabular}{cccccc}
\hline \multirow{2}{*}{ Parameter } & \multicolumn{2}{c}{ Mean \pm SD } & & & \\
\cline { 2 - 4 } & Study group & Control group & t-value & df & P-Value \\
\hline $\begin{array}{c}\text { Salivary flow rate } \\
\text { ml/min }\end{array}$ & $0.38 \pm 0.38$ & $0.47 \pm 0.19$ & 2.152 & 68 & \\
$\begin{array}{c}\text { Salivary PH } \\
\text { Salmificant }\end{array}$ & $7.35 \pm 0.37$ & $7.50 \pm 0.25$ & 2.106 & 68 & \\
\hline
\end{tabular}

Table (4) illustrated that the distribution of the fruit juice intake in the study and control group, a significant difference was noted between them $(\mathrm{P}$ $<0.05)$. Table (5) demonstrated that the distribution of the carbonated drink 
intake in the study and control group, a significant difference was noted between them $(\mathrm{P}<0.05)$.

The results of both fruit juice and carbonated drink intake were in agreement with Jarvinen et al. ${ }^{(8)}$ Johansson et al. ${ }^{(9)}$ and Dugmore and Rock. ${ }^{(19)} \mathrm{Si}$ nce the last occupational war in Iraq, soft drinks become readily available, relatively cheap and the convenient storage possibilities of bottled and canned beverages are important considerations which may increase the intake of these products, however the unstable situation restrict any documented data concerning this subject.

Table (6) illustrated that the distribution of study and control group according to method of drinking, no significant differences have been observed between them $(\mathrm{P}>0.05), 88.6 \%$ of study group and $94.3 \%$ of control group were drink directly from container, this reflect the fashion of drinking method among Iraqi children and it was in accordance with the fashion of drink in Saudi Arabia since all the adolescent in study and control groups were drink directly from can as had been shown by Johansson et al. ${ }^{(9)}$

Table (7) showed that drinking at night habit was higher in study group $(31.4 \%)$ than in control group $(17.1 \%)$, however no significant difference had been observed between study and control group ( $\mathrm{P}>0.05)$, this contradicts with others who reported significant association between erosion and drinking at night habit of the soft drink ${ }^{(20,21)}$, perhaps in larger sample size the difference will be sharper.

Table (4): Distribution of study and control group by fruit juice intake

\begin{tabular}{cccccc}
\hline \multirow{2}{*}{ Fruit juice intake/day } & \multicolumn{2}{c}{ Study group } & \multicolumn{2}{c}{ Control group } & \multirow{2}{*}{$\boldsymbol{P}$-Value } \\
\cline { 2 - 5 } & Number & Percentage & Number & Percentage & \\
\hline Little and Irregular & 20 & 57.1 & 34 & 97.1 & \\
One time daily & 14 & 40 & 1 & 2.9 & Significant \\
Two times or more daily & 1 & 2.9 & 0 & 0.0 & \\
Total & 35 & 100 & 35 & 100 & \\
\hline
\end{tabular}

Table (5): Distribution of study and control group by carbonated drink intake

\begin{tabular}{ccccccc}
\hline \multirow{2}{*}{ Carbonated drink intake } & \multicolumn{2}{c}{ Study group } & \multicolumn{2}{c}{ Control group } & \multirow{2}{*}{$\boldsymbol{P}$-Value } \\
\cline { 2 - 5 } & Number & $\boldsymbol{\%}$ & Number & $\%$ & \\
\hline 2 times/ week & 9 & 25.7 & 31 & 88.6 & \\
4 times/week & 20 & 57.1 & 3 & 8.6 & Significant \\
6 times/week & 6 & 17.1 & 1 & 2.9 & \\
Total & 35 & 100 & 35 & 100 & \\
\hline
\end{tabular}


Table (6): Distribution of methods of drinking in study and control group.

\begin{tabular}{|c|c|c|c|c|c|}
\hline \multirow{2}{*}{ Method of drinking } & \multicolumn{2}{|c|}{ Study group } & \multicolumn{2}{|c|}{ Control group } & \multirow{2}{*}{$P$-Value } \\
\hline & Number & $\%$ & Number & $\%$ & \\
\hline Directly from container & 31 & 88.6 & 33 & 94.3 & \multirow{4}{*}{ No Significant } \\
\hline Drink and swish & 4 & 11.4 & 0 & 0.0 & \\
\hline With straw & 0 & 0.0 & 2 & 5.7 & \\
\hline Total & 35 & 100 & 35 & 100 & \\
\hline
\end{tabular}

Table (7): Distribution of drinking at night habit in study and control group

\begin{tabular}{cccccc}
\hline \multirow{2}{*}{ Drinking at night } & \multicolumn{2}{c}{ Study group } & \multicolumn{2}{c}{ Control group } & \multirow{2}{*}{$\boldsymbol{P}$-Value } \\
\cline { 2 - 5 } & Number & $\boldsymbol{\%}$ & Number & $\boldsymbol{\%}$ & \\
\hline Yes & 11 & 31.4 & 6 & 17.1 & \\
No & 24 & 68.6 & 29 & 82.9 & No Significant \\
Total & 35 & 100 & 35 & 100 & \\
\hline
\end{tabular}

\section{CONCLUSION}

The prevalence of dental erosion in Mosul city is relatively low. Low salivary flow rate and low PH positi-vely associated with dental erosion gr-oup, while positive relationship was found between high acidic soft drink intake and dental erosion group a neg-ative relationship was found between drinking habit, time of drinking and dental erosion group

\section{REFERENCES}

1. Shafer W, Hine M, Levy B, Tomich C. Regressive alteration of the teeth, In: A Textbook of Oral Pathology. $4^{\text {th }}$ ed. Philadelphia WB Saunders Co. 1984; Pp: 318338, 406-478.

2. Chuajedong P, Leggat U, Kertpon D, Wong V, Benjakul P. Associated factors of tooth wear in southern Thailand. J Oral Rehabil. 2002; 29: 997-1002.

3. Johansson AK, Johansson A, Birkhed D, Omar R, Baghdadi S, Carlsson GE. Dental erosion, soft drink intake and oral health in young Saudi men and the development of system for assessing erosive anterior tooth wear. Acta Odontal Scand. 1996; 54: 369-378.

4. Show L, Smith AJ. Dental erosion the problem and some practical solutions. $\mathrm{Br}$ Dent J. 1998; 186: 115-118.
5. Harley K. Tooth wear in the child and the youth. Br Dent J. 1999; 186: 492-496.

6. Myklebust S, Espelid I, Svalestad S, Tveit A. Dental health behavior, gastro esophageal disorders and dietary habits among Norwegian recruits in 1990 and 1999. Acta Odontal Scand. 2003; 61: 100-104.

7. Woltgens J, Vingerling P, Joland MA, Bervotts D. Enamel erosion and Saliva. Clinc Prev Dent. 1985; 73: 8-10.

8. Jarvinen V, Rytomaa I, Heinonen O. Risk factors in dental erosion. J Dent Res. 1991; 70: 942-947.

9. Johansson AK. On dental erosion and associated factors. Swed Dent J. 2002; supplement: 156.

10. Sanchez G, Preliasco M. Salivary PH changes during soft drinks consumption in children. Int J Pediat Dent. 2003; 13: 251275.

11. Smith BG, Knight JK. An index for measuring the wear of teeth. Br Dent J. 1984; 156: 435-338.

12. Millward A, Show L, Smith A. Dental erosion in four year old children from differing socioeconomic backgrounds. J Dent Child. 1994; 61:263-266.

13. Lussi A. Dental erosion, clinical diagnosis and case history taking. Euro J Oral Sci. 1996; 104: 191-198.

14. Deery C, Wager ML, Longbottom C, Simon R, Nugent ZJ. The prevalence of dental erosion in United States and United King- 
dom sample of adolescents. Pediat Dent. 2000; 22: 505-510.

15. AL-Majed I, Maguire A, Murray J. Risk factors of dental erosion in 5-6 year old and 12-14 year old boys in Saudi Arabia. Commun Dent Oral Epidmiol. 2002; 30: 38-46.

16. Dugmore CR, Rock WP. The prevalence of tooth erosion in 12 year old children. $\mathrm{Br}$ Dent J. 2004; 196: 279-282.

17. O'sullivan E, Curzon M. Salivary factors affecting dental erosion in children. Caries Res. 2000; 34: 82-87.

18. Bartlett DW, Coward PY, Nikkah C, Wilson RF. The prevalence of tooth wear in cluster sample of adolescent school children and its relationship with potential expl- anatory factors. $B r$ Dent $J .1998 ; 184$ : 125-129.

19. Dugmore CR, Rock WP. A multifactorial analysis of factors associated with dental erosion. Br Dent J. 2004; 196: 283-286.

20. Millward A, Show L, Smith AJ, Rippin J, Harrington E. The distribution and severity of tooth wear and the relationship between erosion and dietary constituents in a group of children. Int J Pediat Dent. 1994; 4: 151-157.

21. AL-Malik MI, Holt RD, Bedi R. The relationship between erosion, caries and rampant caries and dietary habits in preschool children in Saudi Arabia. Int J Pediat Dent. 2001; 11: 430-439. 